\title{
EVOLUTIONARY AND PROGNOSTIC PARTICULARITIES IN PACIENTS WITH COPD, CHRONIC COR PULMONALE AND COVID-19
}

\author{
Nicoleta - Alina Popa ${ }^{1}$, Adina - Marieta Sipos ${ }^{1}$, Mircea Ioachim Popescu ${ }^{2}$ \\ ${ }^{1}$ The Municipal Hospital of Oradea \\ ${ }^{2}$ County Clinical Emergency Hospital of Oradea
}

\begin{abstract}
COPD is a chronic disease of the respiratory airways due to the partially reversible obstruction of the airflow caused by an abnormal inflammatory response to toxic substances, most often to cigarette smoke ${ }^{(1)}$. COVID-19 is a mild to severe respiratory disease caused by a coronavirus from the Betacoronavirusgenus ${ }^{(2)}$. Patients with COPD have a major risk of COVID-19 infection. Treating patients with COPD, chronic cor pulmonale and COVID-19 is a current challenge.
\end{abstract}

Keywords: COPD, cor pulmonale, COVID-19.

\section{Rezumat}

BPOC este o afecțiune cronică a căilor respiratorii respiratorii ca urmare a obstrucției parțial reversibile a fluxului de aer cauzată de un răspuns inflamator anormal la substanțe toxice, cel mai adesea la fumul de țigară ${ }^{(1)}$. COVID-19 este o afecțiune respiratorie ușoară până la severă determinată de un coronavirus din genul Betacoronavirus ${ }^{(2)}$. Pacienții cu BPOC prezintă un risC major de infecție cu COVID-19. Tratarea pacienților cu BPOC, cord pulmonar cronic și COVID-19 este o provocare actuală.

Cuvinte cheie: BPOC, cord pulmonar, COVID-19.

\section{Introduction}

COPD, CCP and COVID-19 are associated with a decrease in the quality of life, and increased morbidity and mortality. An important complication in the evolution of COPD is the chronic cor pulmonale - CCP. The evolution and prognosis of these patients are greatly tied to risk factors, seeking medical attention early on from the onset of the first symptoms, clinical and paraclinical data, as well as treatment that is applied as promptly as possible. The major risk factor for COPD is smoking cigarettes, and the index for packs / year is very important in this regard ${ }^{(3)}$. As secondary risk factors, we can list: genetic factors, a history of childhood respiratory illness, pollution, occupational respiratory noxious matter (mineral dust), passive smoking.

COPD is a slow process that develops progressively, with the major complication of 
INTERNAL MEDICINE Original Papers

chronic cor pulmonale. Infection with COVID19 in patients with COPD can be fatal, the diagnosis of the form of COVID-19 infection being influenced most of the time by the degree of severity of COPD.

\section{Aim of the study}

The aim of this study is to shed light on the major impact of COVID-19 infection in what concerns patients with COPD and chronic cor pulmonale.

\section{Material and method}

Between December 2020 and June 2021, 100 patients with COPD, Chronic cor pulmonale and COVID-19 infection were assessed at “Dr. Gavril Curteanu" Municipal Clinical Hospital, in the extended Pneumology Department. The systemic inflammation caused by COVID19 worsens the pre-existing hypoxia that these patients suffer from. Hypoxia, respiratory acidosis, hydroelectrolytic and mineral imbalances represent a considerable arrhythmogenic substrate for those affected by COPD, Chronic cor pulmonale and COVID19 infection.

Hypoxia, hypercapnia, oxidative stress, hypoxia-inducible factor 1 lead to pulmonary vasoconstriction, pulmonary hypertension and, subsequently, right ventricular hypertrophy, followed by diastolic dysfunction ${ }^{(4)}$. Pro-fibrotic remodeling of the atrial tissue is promoted, which increases the risk of cardiac arrhythmia in these patients.

\section{Results}

The study was divided into 2 sub-studies:

1. The role of inflammatory biomarkers in patients with COPD, Chronic cor pulmonale and COVID-19 infection.

2. The evolution and prognosis of patients with COPD, Chronic cor pulmonale and COVID-19 after pharmacological therapy that is undergone as promptly as possible.

We assessed the influence of high inflammatory biomarker values (CRP, LDH, FERRITIN, FIBRINOGEN) on the severity of COPD and COVID-19 infection, as well as on the number of days of hospitalization ${ }^{(5,6)}$.

The first stage of the study contains the percentage of COPD cases in relation to the total number of admissions to the extended Pneumology 2 department of the "Dr. Gavril Curteanu" Municipal Clinical Hospital of Oradea throughout the December 2020 - May 2021 period of time.

The risk of infection with SARS-Cov-2 for COPD patients is very high, and, during this pandemic, spirometry is difficult to perform, all patients with respiratory symptoms are mandatorily investigated for an infection with the SARS-Cov-2 virus as well. 


\begin{tabular}{|l|l|l|}
\hline & Total & COPD \\
\hline Number & 489 & 126 \\
\hline Percentage & $80 \%$ & $20 \%$ \\
\hline
\end{tabular}

Table 1. Ratio between the number of COPD cases to the total number of admissions

\begin{tabular}{|l|l|l|}
\hline Age & Number & Percentage \\
\hline $41-50$ Years Old & 8 & $6.34 \%$ \\
\hline $51-60$ Years Old & 48 & $38.09 \%$ \\
\hline $61-70$ Years Old & 53 & $42.06 \%$ \\
\hline $71-80$ Years Old & 10 & $7.94 \%$ \\
\hline$>80$ Years Old & 7 & $5.56 \%$ \\
\hline Total & $\mathbf{1 2 6}$ & $\mathbf{1 0 0} \%$ \\
\hline
\end{tabular}

Table 2. The proportions of COPD patients

\begin{tabular}{|l|l|l|}
\hline Sex & Number & Percentage \\
\hline Women & $\mathbf{4 8}$ & $\mathbf{3 8 . 0 9 \%}$ \\
\hline Men & $\mathbf{7 8}$ & $\mathbf{6 1 . 9 1 \%}$ \\
\hline
\end{tabular}

Table 3. The men / women ratio

\begin{tabular}{|l|l|l|}
\hline Environment & Number & Percentage \\
\hline Rural & 98 & $77.77 \%$ \\
\hline Urban & 28 & 22.23 \\
\hline
\end{tabular}

Table 4. Patient distribution with respect to their environment

\begin{tabular}{|l|l|l|l|l|}
\hline Age & Men & Women & Men \% & Women \% \\
\hline $41-50$ years old & 5 & 3 & $6 \%$ & $6 \%$ \\
\hline $51-60$ years old & 21 & 27 & $27 \%$ & $56 \%$ \\
\hline $61-70$ years old & 37 & 16 & $47 \%$ & $33 \%$ \\
\hline $71-80$ years old & 9 & 1 & $12 \%$ & $2 \%$ \\
\hline$>80$ years old & 6 & 1 & $8 \%$ & $2 \%$ \\
\hline Total & $\mathbf{7 8}$ & $\mathbf{4 8}$ & $\mathbf{1 0 0} \%$ & $\mathbf{1 0 0} \%$ \\
\hline
\end{tabular}

Table 5. The distribution of COPD cases depending on age and sex 
A differential diagnosis of the symptoms caused by a COVID-19 infection and the symptoms present in COPD is important.

\section{Results regarding the demographic factors:}

- The age of the patients is presented in table 2. The case incidence increases along with age, most patients are aged 60 to 80 .

- The sex of the patients is presented in table 3. $61.91 \%$ of all cases was represented by patients of the male sex, due to their susceptibility to develop COPD, according to the data in the specialized literature.

- Environment. With respect to their environment, we can see an increased incidence among the patients who live in the rural area.

The values of patients' inflammatory biomarkers at admission

Out of the 126 patients included in the study, 102 patients displayed high c-reactive protein values, of which 54 patients displayed values exceeding $200 \mathrm{mg} / \mathrm{dL}$, which is $53 \%$, while the ones exceeding values of other 300 $\mathrm{mg} / \mathrm{dL}$ were 12 in number, representing $12 \%$. Values of over $120 \mathrm{mg} / \mathrm{dL}$ were found in a number of 26 patients, which amounts to $25 \%$.

Out of the 97 patients with ferritin that exceeded normal values ( $\mathrm{NV}=300 \mathrm{mcg} / \mathrm{L}$ ), 54 patients displayed values of over $500 \mathrm{mcg} / \mathrm{L}$, amounting to $56 \%, 31$ patients had values of over $100 \mathrm{mcg} / \mathrm{L}$ with $32 \%$, while 12 patients displayed very high values of over 1,500 $\mathrm{mcg} / \mathrm{L}$, with $12 \%$.

\section{Results after studying the complica- tions}

In what concerns complications due to COPD, these remain a continuous challenge for clinicians, as these patients have a very high risk of premature death, both because of the disease itself, as well as the complications.

In the previous figure, we can highlight the increased number of patients with chronic cor pulmonale, a $55.55 \%$ percentage, while over $90 \%$ of cases was represented by patients with severe hypoxemia and exacerbations. Atrial fibrillation is also caused by COPD, with $29.36 \%$ for a number of 37 patients.

Chronic cor pulmonale is one of the severe complications of COPD, which actually represents the development of right heart failure, secondary to COPD-induced pulmonary hypertension.

Treatment of airflow obstruction and hypoxemia is very important in cases of chronic cor pulmonale ${ }^{(7)}$. Timely diagnosis of chronic cor pulmonale is of major importance for the management, evolution and prognosis of COPD. The high-specificity and -sensitivity imaging test which confirms the 


\begin{tabular}{|l|l|l|}
\hline Biomarker & Number & Percentage \\
\hline C-reactive protein $>100 \mathrm{mg} / \mathrm{dL}$ & 102 & $80.95 \%$ \\
\hline Ferritin $>300 \mathrm{mg} / \mathrm{L}$ & 97 & $76.98 \%$ \\
\hline $\mathrm{LDH}>240 \mathrm{U} / \mathrm{L}$ & 88 & $69.84 \%$ \\
\hline Fibrinogen $>400 \mathrm{mg} / \mathrm{dL}$ & 67 & $53.17 \%$ \\
\hline Procalcitonin $>0,5 \mathrm{ng} / \mathrm{dL}$ & 45 & $35.71 \%$ \\
\hline
\end{tabular}

Table 6. Inflammatory biomarkers

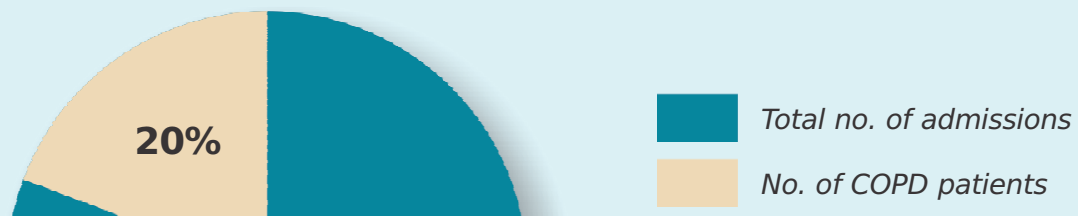

Figure 1. The percentage of COPD cases in relation to the $80 \%$ total number of admissions

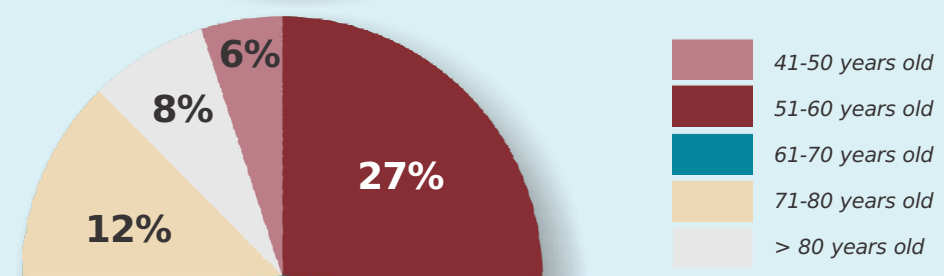

Figure 2. Distribution of men based on age

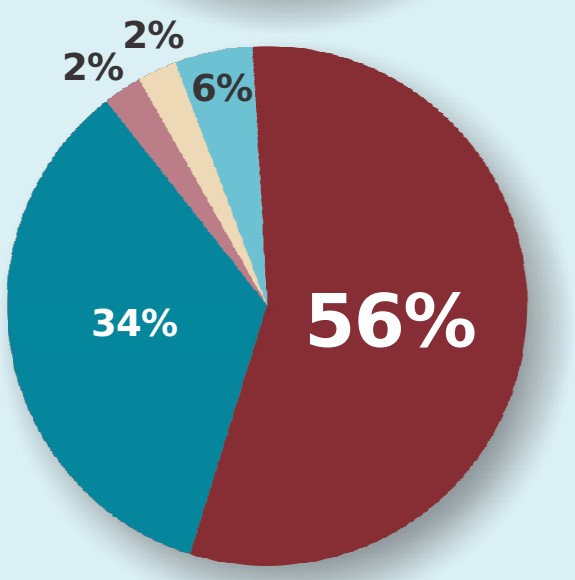

41-50 years old

51-60 years old

61-70 years old

71-80 years old

$>80$ years old

Figure 3. Distribution of women based on age 
INTERNAL MEDICINE Originai Papers

presence of chronic cor pulmonale is the transthoracic or transesophageal cardiac ultrasound $^{(8)}$.

The period of hospitalization is part of the study parameters, thus, we have had patients whose hospital stay was 14-days long, but also patients who needed a longer stay.

\section{Discussions}

The inflammatory markers characterize the inflammation of the respiratory airways in COPD, as well as the systemic inflammation in COVID-19.

This study aimed to determine the role of these inflammatory biomarkers in the evolution and prognosis of patients with COPD, Chronic cor pulmonale and COVID-19.

The patients were closely monitored throughout their hospitalization, which was at least 14 days long. The inflammatory biomarkers measured at a maximum interval of 2 days played a major role in closely monitoring the patients. We thus noticed that patients with high CRP and ferritin values had an unfavorable evolution, resulting in their death.

There were a number of 57 deaths among the studied sample of patients, who presented associated severe comorbidities.

\section{Conclusions}

COPD is a major risk factor for the development of Chronic cor pulmonale.

COVID-19 infection in this category of patients promoted major systemic imbalances: hyperinflation, marked hypoxia, hypercapnia, respiratory acidosis, systemic bacterial infections, consequently, profoundly altered inflammatory biomarkers. The healing percentage related to the patients depended on the form of COVID infection, the degree of COPD, the risk category for the exacerbation of COPD, as well as the standard, updated treatment applied as promptly as possible. The evolution of the patients was closely monitored after their infection with COVID$19^{(9,10)}$. 


\begin{tabular}{|l|l|l|}
\hline Period of hospitalization & 14 days & $>14$ days \\
\hline Number & 42 & 84 \\
\hline Percentage & $33.33 \%$ & $66.66 \%$ \\
\hline
\end{tabular}

Table 7. Distribution in relation to the number of days of hospitalization

\begin{tabular}{|l|l|l|}
\hline $\begin{array}{l}\text { Total number of COPD, CCP, COVID -19 } \\
\text { patients }\end{array}$ & 126 & $100 \%$ \\
\hline Number of deaths & 57 & $45.23 \%$ \\
\hline
\end{tabular}

Table 8. The ratio between the deaths and the total number of hospitalizations
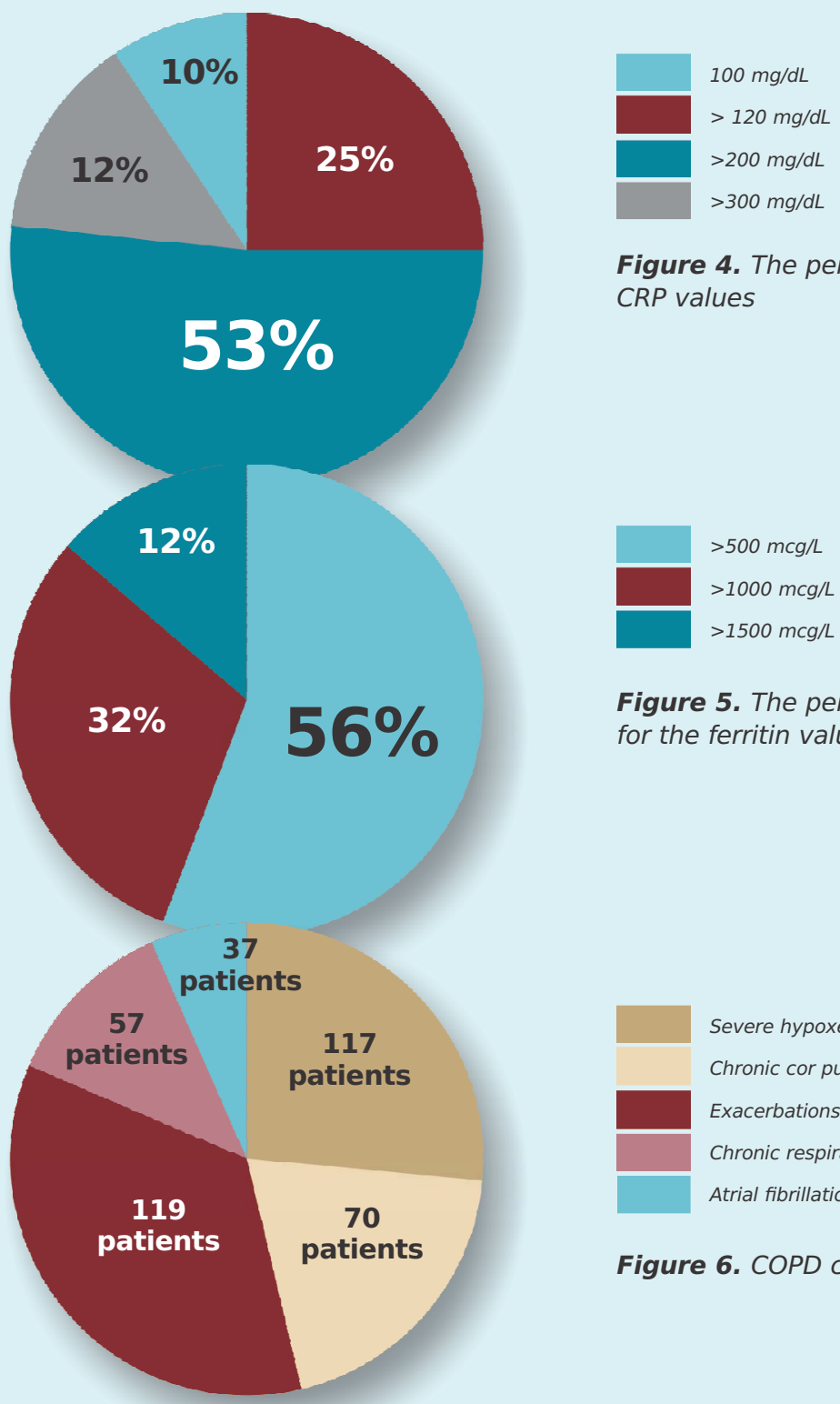

Figure 4. The percentages for CRP values

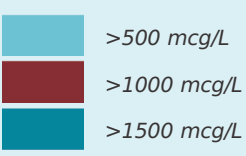

Figure 5. The percentages for the ferritin values

Severe hypoxemia

Chronic cor pulmonale

Exacerbations

Chronic respiratory failure Atrial fibrillation

Figure 6. COPD complications 


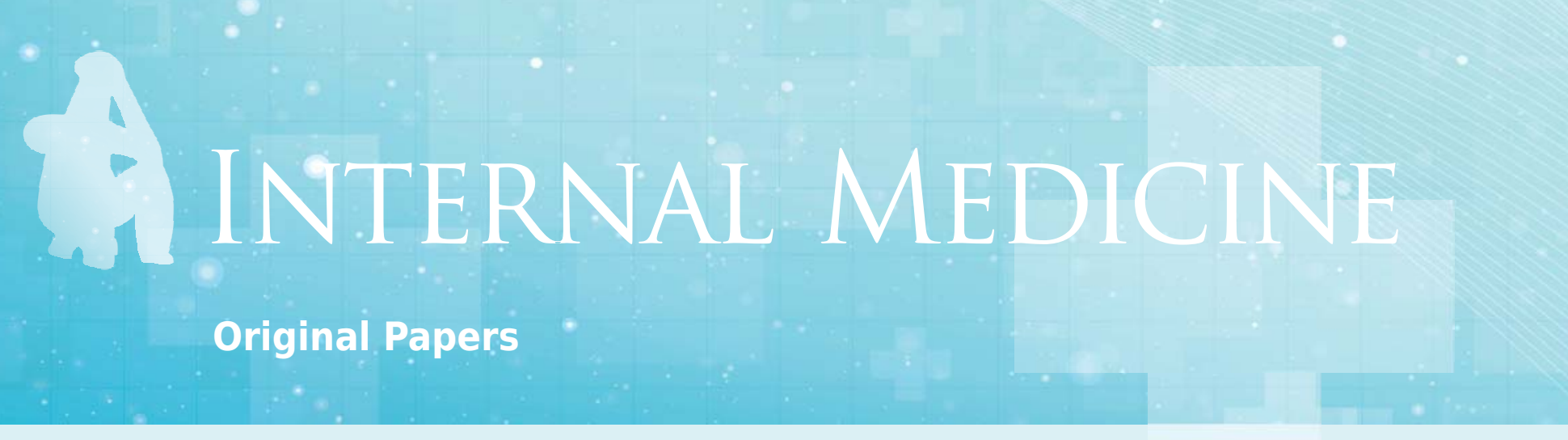

\section{References}

1. The MERCK MANUAL TWENTIETHEDITION, 2018.

2. Postma DS, Bush A, vsn den Berger M. Risk factors and early origins of chronic obstructive pulmonary disease Lance 2015.

3. WHO-Chronic Cor pulmonale Report of an Expert Committee Circulation 1963.

4. http://www.who.int/news-room/fact-sheets/detail/ chronic-obstructive-pulmonary-disease-(copd).

5. Duvoix A. Dickens J, Imram H., et. Al-Blood fibrinogen as a biomarker of chronic obstructive pulmonary disease. $T$ thoarax 2013.

6. Fattouh M, Alkady O.- Inflammatory biomarkers in chronic obstructive pulmonary disease, Egyptian Journal of Chest Diseases And Tuberculosis 2014.

7. Bartolome R. C. et al- Inflammatory Biomarkers
Improve Clinical Prediction of Mortality in Chronic Obstructive Pulmonary Disease, Am. Journal Respir. Crit. Care. Med 2012

8. Augusti A., Eduards L.D., Rennards S.I., - persistent systemic inflammation is associated with poor clinical outcomes in COPD-Biomarkers in clinical Practice 20121 9. Global Initiative for Chronic Obstructive Lung Disease: Global Strategy For The Diagnosis, Management And Preven-tion Of Chronic Obstructive Pulmonary Disease 2021 report.

10. RuxandraUlmeanu, Florin DumitruMihaltan, Cristian Oancea - Recomandari de diagnostic sitratament in Bronhopneumopatia Cronica Obstructiva [Diagnosis and Treatment Recommendations for Chronic Obstructive Brocnhopneumopathy], Medicala Publishing House 2019 